\title{
Risk Factors of Low Back Pain in Adults Attending a Tertiary Hospital in Uyo, Nigeria \\ AC Jiman, EA Etukumana
}

\begin{abstract}
Background: Low back pain is a common musculoskeletal disorder. However, there is very little information about low back pain in developing Countries. This study aimed at identifying sociodemographic and lifestyle risk factors for low back pain in adults attending the General Outpatient Clinic of the University of Uyo Teaching Hospital, Uyo, Nigeria.

Methods: A cross-sectional study design was utilized. A structured questionnaire was used to obtain information from 400 consenting adults aged 18 years and above, attending the General Out-patient Clinic of University of Uyo Teaching Hospital from May 2011 to July 2011. The data obtained were analysed using Epi Info statistical software version 3.2.2.

Results: The mean age of the subjects was $38 \pm 14.2$ years. There were 176 males and 224 females with a ratio of 1:1.3. The period prevalence of low back pain was 31\%. Statistically significant risk factors were: age $\left(x^{2}=103.3, \mathrm{p}<0.0001\right)$, educational status $\left(x^{2}=13.82, \mathrm{p}=0.0002\right)$, marital status $\left(x^{2}=\right.$ $25.72, \mathrm{p}<0.0001)$, place of residence $\left(x^{2}=6.04, \mathrm{p}=0.01\right)$, alcohol consumption $\left(x^{2}=11.96, \mathrm{p}=\right.$ $0.0005)$, cigarette smoking $\left(x^{2}=10.02, \mathrm{p}=0.0015\right)$ and high body mass index [BMI] $\left(X^{2}=120.29, \mathrm{p}<\right.$ $0.0001)$. Gender was not statistically significant $\left(X^{2}=1.96, \mathrm{p}=0.16\right)$.

Conclusion: This study showed that an active age-group, low educational status, being married, rural residence, alcohol consumption, cigarette smoking and a high BMI were associated with low back pain. Health education on the risk factors of low back pain and the need for lifestyle modification should be encouraged among the populace especially in rural settings.
\end{abstract}

Keywords: Adult, low back pain, risk factors, Uyo

\section{Factores de Riesgo del Dolor Lumbar en Adultos que Asisten a un Hospital Terciario en Uyo, Nigeria}

AC Jiman, EA Etukumana

\begin{abstract}
RESUMEN
Antecedentes: El dolor lumbar es un trastorno musculoesquelético común. Sin embargo, existe muy poca información sobre el dolor de espalda baja en los países en desarrollo. Este estudio tuvo como objetivo identificar factores de riesgo sociodemográficos y de estilo de vida en relación con el dolor lumbar en adultos que acudían a la Clínica General Ambulatoria del Hospital Docente de la Universidad de Uyo, en Uyo, Nigeria.

Métodos: Se utilizó un diseño de estudio transversal. Se utilizó un cuestionario estructurado para obtener información con consentimiento de 400 adultos de 18 años o más, quienes acudieron a la Clínica General Ambulatoria del Hospital Docente de la Universidad de Uyo, de mayo de 2011 a julio de 2011. Los datos obtenidos se analizaron usando la versión 3.2.2 del software estadístico Epi Info.

Resultados: La edad media de los sujetos fue de $38 \pm 14.2$ años. Había 176 varones y 224 mujeres para una proporción de 1:1.3. La prevalencia de periodo de dolor de lumbar fue de 31\%. Los factores de riesgo estadísticamente significativos fueron: edad $\left(x^{2}=103.3, \mathrm{p}<0.0001\right)$, nivel educacional $\left(x^{2}=\right.$ 13.82, $\mathrm{p}=0.0002)$, estado civil $\left(x^{2}=25.72, \mathrm{p}<0.0001\right)$, lugar de residencia $\left(x^{2}=6.04, \mathrm{p}=0,01\right)$, consumo de alcohol $\left(x^{2}=11.96, \mathrm{p}=0.0005\right)$, tabaquismo $\left(x^{2}=10.02, \mathrm{p}=0.0015\right)$, $y$ alto índice de masa cor-
\end{abstract}

From: Department of Family Medicine, University of Uyo Teaching Hospital, Abak Road, Uyo, Akwa Ibom State, Nigeria.
Correspondence: Dr AC Jiman, Department of Family Medicine, University of Uyo Teaching Hospital, Abak Road, Uyo, Akwa Ibom State. Nigeria. Email: abduljiman@yahoo.com 
poral $[I M C]\left(x^{2}=120.29, \mathrm{p}<0.0001\right)$. El género no fue estadísticamente significativo $\left(x^{2}=1.96, \mathrm{p}=\right.$ $0.16)$.

Conclusión: Este estudio demostró que una edad activa, un bajo nivel educacional, estar casado, tener residencia rural, el consumo de alcohol, el fumar cigarrillos, y un IMC alto se asociaron con el dolor lumbar. La educación para la salud sobre los factores de riesgo del dolor de espalda baja y la necesidad de modificar el estilo de vida, deben fomentarse en la población, especialmente en los entornos rurales.

Palabras claves: Adulto, dolor lumbar, factores de riesgo, Uyo

West Indian Med J 2017; 66 (1): 96

\section{INTRODUCTION}

Low back pain is a common musculoskeletal disorder. It is a considerable problem affecting people in the developed and developing countries (1). However, there is little information about low back pain in the general population in developing countries. Some authors have suggested that scarcity of reports from developing countries may be due to the fact that low back pain is considered less important in comparison to other health problems (2).

Low back pain has been associated with several risk factors which include lifestyle factors (such as smoking), psychosocial factors related to work (high work stress, low job satisfaction), job-related factors (work activities, work place condition) and sociodemographic factors [age, gender] (2-4). The association between age, body mass index (BMI), smoking and alcohol consumption with low back pain has produced controversial results as reported in the literature (5-7). Studies have reported a high prevalence of low back pain among individuals aged between $30-60$ years $(8,9)$. There are mixed reports on gender as a risk factor of low back pain depending on the occupation of the individuals (10-12). Being married, living in a rural setting and having a low level education have been identified as risk factors of low back pain (13-20).

There are studies that have shown association of smoking with low back pain $(3,7,21)$. However, other studies did not find any significant association between smoking and low back pain $(22,23)$. Well-designed studies are lacking on the association between alcohol and low back pain (7). However, a systematic review by Leboeuf-yde concluded that alcohol consumption does not seem to be associated with low back pain (7).

There are mixed reports on the association between BMI and low back pain (24-29). This study, therefore, was aimed at identifying sociodemographic and lifestyle risk factors of low back pain in adults attending the General Out-patient Clinic of the University of Uyo Teaching Hospital.

\section{SUBJECTS AND METHODS}

This was a cross-sectional, hospital-based study that was conducted at the General Out-patient Clinic of the University of Uyo Teaching Hospital, Uyo, Nigeria, from May 2011 to July 2011. A total of 400 subjects aged 18 years and above were selected for the study using systematic sampling technique. The first subject was randomly selected while subsequent selection of subjects was based on a pre-determined sampling interval. The study was approved by the Research and Ethics committee of the University of Uyo Teaching Wspital. Written informed consent was obtained from the subjects after explaining the nature and objective of the study to them. All consenting adults aged 18 years and above were included in the study while non-consenting subjects, those less than 18 years and very ill patients were excluded. Each subject was administered a semi-structured questionnaire which sought information on sociodemographic characteristics, the presence or absence of low back pain, history of alcohol consumption and cigarette smoking. Anthropometric measurements such as weight, height and BMI were also carried out on the patients. The weight and height of the subjects were measured using the RGZ-120 Health scale. The BMI was calculated using the formula: weight in $\mathrm{Kg} /$ height in $\mathrm{m}^{2}$.

Data entry and analysis was done using Epi Info statistical software version 3.2.2 [CDC Atlanta, Georgia, USA] (30). The means, frequencies and statistical association of variables were ascertained.

\section{RESULTS}

Four hundred subjects were recruited for the study. The sociodemographic characteristics of the study subjects is shown in Table 1. There were 176 (44\%) male and 224 (56\%) female subjects in the study population with male to female ratio of $1: 1.3$. The mean \pm standard deviation of the subjects' age was $38 \pm 14.2$ years.

The risk factors for low back pain in the study subjects are shown in Table 2. Subjects above 40 years of age had more frequency of low back pain when compared to those below 40 years of age $\left(\mathrm{X}^{2}=103.3, p<0.0001\right)$. The proportion of male subjects who had low back pain was more compared to the female subjects (34.7\% versus $28.1 \%$ ) but was not statistically significant $\left(\mathrm{X}^{2}=1.97, p=0.16\right)$.

A significant proportion of subjects who were currently married had low back pain compared to those who were not currently married $\left(\mathrm{X}^{2}=25.72, p<0.0001\right)$. Subjects with low level education had more frequency of low back pain compared to those with high level education $\left(\mathrm{X}^{2}=13.82, p=\right.$ 0.0002). Subjects who dwelt in rural areas also had more low 
Table 1: Sociodemographic distribution of the study subjects

\begin{tabular}{|c|c|c|c|c|}
\hline Variable & $\begin{array}{l}\text { Frequency } \\
\text { Male n (\%) }\end{array}$ & $\begin{array}{c}\text { Female } \\
\text { n (\%) }\end{array}$ & $\begin{array}{c}\text { Total } \\
(\%)\end{array}$ & $95 \% \mathrm{CI}$ \\
\hline \multicolumn{5}{|l|}{ Age group (years) } \\
\hline \multicolumn{5}{|l|}{$<20$} \\
\hline & $11(6.3)$ & $20(8.90)$ & $31(7.8)$ & $5.4-10.9$ \\
\hline \multicolumn{5}{|l|}{$20-29$} \\
\hline \multirow[t]{2}{*}{$30-39$} & $42(23.9)$ & $70(31.3)$ & $112(28.0)$ & $23.7-32.7$ \\
\hline & $46(26.1)$ & $25(11.2)$ & $71(17.6)$ & $14.2-21.9$ \\
\hline $40-49$ & 35 (19.9) & $41(18.3)$ & $76(19.0)$ & $15.3-23.3$ \\
\hline $50-59$ & $27(15.3)$ & $46(20.5)$ & $73(18.3)$ & $14.7-22.5$ \\
\hline$\geq 60$ & $15(8.5)$ & $22(9.8)$ & $37(9.3)$ & $6.7-12.6$ \\
\hline \multicolumn{5}{|l|}{ Marital status } \\
\hline Single & $63(35.8)$ & $84(37.5)$ & $147(36.6)$ & $32.1-41.7$ \\
\hline Married & $104(59.1)$ & $101(45.1)$ & $205(51.3)$ & $46.2-56.2$ \\
\hline Separated & $3(1.7)$ & $4(1.8)$ & $7(1.8)$ & $0.8-3.7$ \\
\hline Divorced & $0(0.0)$ & $6(2.7)$ & $6(1.5)$ & $0.6-3.4$ \\
\hline Widowed & $6(3.4)$ & $29(12.9)$ & $35(8.8)$ & $6.3-12.1$ \\
\hline \multicolumn{5}{|l|}{ Level of education } \\
\hline No. formal education & $11(6.3)$ & $17(7.6)$ & $28(7.0)$ & $4.8-10.1$ \\
\hline Primary & $45(25.6)$ & $50(22.3)$ & $95(23.8)$ & $19.7-28.3$ \\
\hline Secondary & $73(41.5)$ & $90(40.2)$ & $163(40.8)$ & $35.9-45.8$ \\
\hline Tertiary & $47(26.6)$ & $67(29.9)$ & $114(28.4)$ & $24.2-33.2$ \\
\hline \multicolumn{5}{|l|}{ Occupational status } \\
\hline Unemployed & $44(25.0)$ & $80(35.7)$ & $124(31.0)$ & $26.5-35.8$ \\
\hline Unskilled & $91(51.70$ & $95(42.4)$ & $186(46.5)$ & $41.5-51.5$ \\
\hline Semi-skilled & $20(11.4)$ & $28(12.5)$ & $48(12.0)$ & $9.1-15.7$ \\
\hline Skilled & $21(11.9)$ & $21(9.4)$ & $42(10.5)$ & $7.8-14.0$ \\
\hline \multicolumn{5}{|l|}{ Place of residence } \\
\hline Urban & $94(53.4)$ & $120(53.6)$ & $214(53.5)$ & $48.5-58.5$ \\
\hline Rural & $82(46.6)$ & $104(46.4)$ & $186(46.5)$ & $41.5-51.5$ \\
\hline
\end{tabular}

$n=400$ back pain than those in the urban areas. This was statistically significant $\left(\mathrm{X}^{2}=6.04, p=0.01\right)$.

A significant percentage of the subjects who drank alcohol had low back pain compared to those who did not drink alcohol $\left(\mathrm{X}^{2}=11.96, p=0.0005\right)$. The proportion of subjects with low back pain who smoked cigarettes was significantly more when compared to those who did not smoke cigarettes $\left(\mathrm{X}^{2}=10.02, p=0.0015\right)$. Subjects who were overweight or obese had more low back pain when compared to those who were of normal weight. This was statistically significant $\left(\mathrm{X}^{2}=120.29, p<0.0001\right)$.

\section{DISCUSSION}

This study showed that age, marital status, level of education, place of residence, alcohol consumption, cigarette smoking and BMI were significantly associated with low back pain.

Subjects aged between 40 and 49 years had the highest prevalence of low back pain in this study. This was closely followed by those aged between 30 and 39 years. This finding is almost similar to that reported by Sanya et al (9), who in their study found the prevalence of low back pain to be high among individuals aged between 36 and 40 years. The high prevalence of low back pain in these age groups is not surprising since they are the most active groups.

Low back pain was found to be more prevalent among subjects who were currently married than those who were not currently married (single, separated, divorced or widowed). This was in keeping with reports from other studies $(13,14)$. Knox et al (13), reported an increased prevalence of low back pain among subjects who were currently married compared to those who were not currently married at the time of their study.

Table 2: Risk factors for low back pain in the study subjects

\begin{tabular}{|c|c|c|c|c|c|}
\hline \multirow[t]{2}{*}{ Variable } & \multicolumn{2}{|c|}{ Low back pain } & \multirow{2}{*}{$\begin{array}{l}\text { Total } \\
\text { n (\%) }\end{array}$} & \multirow[t]{2}{*}{$\mathbf{X}^{2}$} & \multirow[t]{2}{*}{$p$-value } \\
\hline & Yes n $(\%)$ & No n $(\%)$ & & & \\
\hline \multicolumn{6}{|c|}{ Sociodemographic factors } \\
\hline \multicolumn{6}{|c|}{ Age-group (years) } \\
\hline$<40$ & $38(30.6)$ & $176(11.2)$ & $214(53.5)$ & 103.3 & $<0.0001$ \\
\hline$\geq 40$ & $86(69.4)$ & $100(10.5)$ & $186(46.5)$ & & \\
\hline \multicolumn{6}{|l|}{ Gender } \\
\hline Male & $61(34.7)$ & $115(65.3)$ & $176(44.0)$ & 1.96 & 0.16 \\
\hline Female & $64(28.1)$ & $161(71.9)$ & $224(56.0)$ & & \\
\hline \multicolumn{6}{|l|}{ Marital status } \\
\hline Currently married & $87(42.4)$ & $118(57.6)$ & $205(51.3)$ & 25.72 & $<0.0001$ \\
\hline Not currently married & $37(19.0)$ & $158(81.0)$ & $195(48.7)$ & & \\
\hline \multicolumn{6}{|l|}{ Educational level } \\
\hline High level education & $70(25.3)$ & $207(74.7)$ & $277(69.3)$ & 13.82 & 0.0002 \\
\hline Low level education & $54(44.0)$ & $69(56.0)$ & $123(30.7)$ & & \\
\hline \multicolumn{6}{|l|}{ Place of residence } \\
\hline Urban & $55(25.7)$ & $159(74.3)$ & $214(53.5)$ & 6.04 & 0.01 \\
\hline Rural & $69(37.0)$ & $117(63.0)$ & $186(46.5)$ & & \\
\hline
\end{tabular}




\begin{tabular}{|c|c|c|c|c|c|}
\hline \multirow[t]{2}{*}{ Variable } & \multicolumn{2}{|c|}{ Low back pain } & \multirow{2}{*}{$\begin{array}{l}\text { Total } \\
\text { n (\%) }\end{array}$} & \multirow[t]{2}{*}{$\mathbf{X}^{2}$} & \multirow[t]{2}{*}{$p$-value } \\
\hline & Yes n (\%) & No n (\%) & & & \\
\hline \multicolumn{6}{|l|}{ Lifestyle factors } \\
\hline \multicolumn{6}{|l|}{ Alcohol intake } \\
\hline Yes & 60 (41.7) & $84(58.3)$ & $144(36.0)$ & 11.96 & 0.0005 \\
\hline No & $64(25.0)$ & $192(75.0)$ & $256(64.0)$ & & \\
\hline \multicolumn{6}{|l|}{ Cigarette smoking } \\
\hline Yes & $22(52.4)$ & $20(47.6)$ & $42(10.5)$ & 10.02 & 0.0015 \\
\hline No & $102(28.5)$ & $256(71.5)$ & $358(89.5)$ & & \\
\hline \multicolumn{6}{|l|}{ BMI } \\
\hline Underweight/normal weight & $40(32.3)$ & $235(85.1)$ & $275(68.8)$ & & \\
\hline Overweight/obese & $84(67.7)$ & $41(14.9)$ & $125(31.2)$ & 120.29 & $<0.0001$ \\
\hline
\end{tabular}

BMI; body mass index

Similarly, Lee et al (14), reported a significant percentage of low back pain in married individuals. There is no clear reason to support the high prevalence of low back pain in subjects who were currently married in this study. Contrary to the finding in this study, research has shown that married individuals tend to be healthier than their single, separated, divorced or widowed counterparts (15). It has been theorized that being married gives advantage in terms of money, encouragement to lead healthy lifestyles, and social and psychological support all of which are protective of health.

Subjects with low level educational attainment in this study had a higher prevalence of low back pain compared to those with high level of education. Studies have shown that less educated people are more likely to be affected by low back pain $(15,16)$. Thus, agreeing with the finding in this study. The causal process linking education and low back pain is not well known. Education may affect the prevalence of low back pain through lifestyle factors such as smoking or obesity. Higher educational attainment is linked to high socio-economic status. Higher socio-economic status has been linked to better health, and better educated people are said to have lifestyles that are physically and emotionally less stressful compared to the less educated people (17).

There was a high prevalence of low back pain in subjects who dwelt in the rural areas compared to those who dwelt in the urban areas in this study. This was similar to findings from other studies which reported that medical visits for degenerative joint disease and low back pain were higher among rural dwellers than in their urban counterparts $(18,19)$. The observed difference between rural and urban dwellers may be due to lower level of education, lower socio-economic status and poorer access to healthcare among rural dwellers.

In this study, subjects who drank alcohol had a higher prevalence of low back pain compared to those who did not drink alcohol. This was in contrast to the report from a systematic review of literature by Lebouef-Yde (7). None of the studies reviewed by Lebouef-Yde reported a significant association between alcohol consumption and low back pain. Alcohol consumption as a risk factor for low back pain has not be extensively studied in medical literature. Therefore, our finding would contribute to the few existing literature.

Subjects who smoked cigarettes had higher prevalence of low back pain than those who did not smoke cigarettes. This finding agreed with reports from previous studies $(3,12,22$, 23). Miwako et al (12), Omokhodion and Sanya (3) in separate studies reported a significant association between smoking and low back pain. Contrasting findings were reported by Oksuz et al (22) and Landry et al (23). According to their study, smoking was not a risk factor for low back pain.

Subjects with high BMI in this study reported a higher prevalence of low back pain than those of normal bodyweight. This finding was similar to that reported by Ingrid et al (25) in a large cross-sectional study. They reported that a high BMI was a risk factor for low back pain. Mohammed and Ziad (26) also concluded that obese patients are at high risk for developing low back pain.

This study is limited by the fact that other risk factors of low back pain were not considered. The subjective rather than objective assessment of low back pain in this study, is another limitation.

In conclusion, our findings in this study showed that an active age-group, being married, low level of education, rural residence, alcohol consumption, cigarette smoking and high BMI were significantly associated with low back pain. Health education on the risk factors for low back pain and the need for lifestyle modification should be encouraged among the populace especially in the rural settings.

\section{ACKNOWLEDGEMENT}

The authors wish to acknowledge the contributions of all other Consultants in the department of Family medicine, UUTH, Uyo, for their useful advices during the preparation of the manuscript. 


\section{REFERENCES}

1. Koes BW, Van Tulder MW, Thomas S. Diagnosis and treatment of low back pain. BMJ 2006; 332: 1430-4.

2. Diara S, Bastaman B, Jofizal J. Static sitting as a risk factor of low back pain. Universa Medicina 2005; 24: 51-110.

3. Omokhodion FO, Sanya AO. Risk factors for low back pain among office workers in Ibadan. Occup Med 2003; 53: 287-9.

4. Fabunmi AA, Aba SO, Odunaiya NA. Prevalence of low back pain among peasant farmers in a rural community in South-west Nigeria. Afr J Med Sci 2005; 34: 259-62.

5. Miranda H, Viikari-Juntara R, Martikainen E, Takala P, Riihimaki H. Physical exercise and Musculoskeletal pain among forest industry workers. Scand J Med Sci Sports 2001; 11: 239-46.

6. Porter JM, Gyi DE. The prevalence of musculoskeletal troubles among car drivers. Occup Med 2002; 52: 4-12.

7. Leboeuf-Yde C. Alcohol and low back pain. A systematic literature review. J Manipulative Physiol Ther 2000; 23: 343-6.

8. Ehrlich GE. Low back pain. Bull World Health Org 2003; 81: 671-6.

9. Sanya AO, Omokhodion FO, Ogwumike OO. Risk factors for low back pain among Hospital workers in Ibadan. J Nig Soc Physiother 2005; 15: $31-4$.

10. Stam HJ, Dommisse AM, Bussmann HJ. Prevalence of low back pain after transfemoral amputation related to physical activity and other prosthesis-related parameters. Disabil Rehabil 2004; 26: 794-7.

11. Leroux I, Brisson C, Montreuil S. Job strain and neck-shoulder symptoms. A prevalence study of women and men white collar workers. Occup Med 2006; 56: 102-9.

12. Miwako N, Kazuhiro S, Akiyoshi I, Shigeru T, Yoshima T, Mitsuo U et al. Prevalence and risk factors of low back pain among professional cooks working in school lunch services. BMC Public Health 2007; 7: 171.

13. Knox J, Orchwski J, Schem DL, Owens BD, Burks R, Belmont PJ. The incidence of low back pain in active duty United States Military Service members. Spine 2011; 15-22.

14. Lee P, Helewa A, Goldsmith CH, Smythe HA, Stitt LW. Low back pain: prevalence and risk factors in an industrial setting. J Rheumatol 2011; 28: 346-51.

15. Kiecolt-Glaser JK, Newton TL. Marriage and Health. Psychological Bulletin 2001; 127: 472-503.

16. Blane D. Commentary. Explanation of the difference in mortality risk between different educational groups. Int J Epidemiol 2003; 32: 355-6.
17. Leclerc A, Gourmelea J, Chastang J, Lanoe J. Low level education and back pain in France: the role of demographic, lifestyle and physical risk factors. Int Arch Occup Environ Health 2009; 82: 643-52.

18. Dionne C, Von korff M, Koepsell T, Checkoway H. Formal education and Back pain: a review. J Epidemiol Comm Health 2001; 55: 455-68.

19. Eberhardt M, Panmuk E. The importance of place of residence: examining health in rural and non-rural areas. Am J Public Health 2004; 94: $1682-86$.

20. Probst JC, Moore CG, Baxley EG, Lommie JJ. Rural-Urban difference in visits to Primary Care Physicians. Fam Med 2002; 34: 609-15.

21. Goldberg MS, Scott SC, Mayo NE. A review of the association between cigarette smoking and development of non-specific back pain and related outcomes. Spine 2000; 25: 995-1014.

22. Oksuz E. Prevalence, risk factors and preference- based health status of low back pain in a Turkish population. Spine 2006; 31: 968-72.

23. Landry MD, Raman SR, Sulway C, Golightly YM, Hamdan E. Prevalence and risk factors associated with low back pain among health care providers in a Kuwait hospital. Spine 2008; 33: 539-45.

24. Hertz RP, Unger AN, McDonald M, Lustik MB, Biddulph-Krentar J. The impact of obesity on work limitations and cardiovascular risk factors in the US work force. J Occup Environ Med 2004; 46: 1196-203.

25. Ingrid H, Hagen $\mathrm{K}$, Oystein $\mathrm{N}$, Ivar H, Zwart JA. The impact of BMI on the prevalence of low back pain. The HUNT study. Spine 2010; 35: 764 8 .

26. Mohammed H, Mohammed T, Ziad M. The association of low back pain with obesity in one of the Primary Health Care Centre. Bahrain Med Bull 2000; 22: 1-3.

27. Leboeuf-Yde C. Body weight and low back pain. A systematic literature review of 56 journal articles reporting on 65 epidemiological studies. Spine 2000; 25: 226-37.

28. Timothy AM, Leon G. Is obesity a risk factor for low back pain? An example of using the evidence to answer clinical questions. J Chiropr Osteopath 2005; 13: 2 .

29. Woolf AD, Breedveld FC, Krien TK. Controlling the obesity epidemiology is important for maintaining musculoskeletal health. Ann Rheum Dis 2006; 65: 1401-2.

30. Centre for Disease Control (CDC). Epi info software version 3:2:2 CDC, Atlanta, Georgia. USA. 